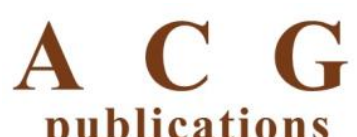

Rec. Nat. Prod. $14: 5$ (2020) 372-377

records of natural products

\title{
Antimicrobial, Larvicidal Activities and Composition of the Leaf Essential Oil of Magnolia coco (Lour.) DC
}

\author{
Nguyen T. Chung $\odot{ }^{1}$, Le T. Huong $\odot^{2, *}$ and Isiaka A. Ogunwande $\odot^{3, *}$ \\ ${ }^{1}$ Graduate University of Science and Technology, Vietnam Academy of Science and Technology, 18Hoang \\ Quoc Viet, Cau Giay, Hanoi, Vietnam \\ ${ }^{2}$ School of Natural Science Education, Vinh University, 182 Le Duan, Vinh City, Nghệ An Province, \\ Vietnam \\ ${ }^{3}$ Foresight Institute of Research and Translation, Nigeria
}

(Received February 04, 2020; Revised February 24, 2020; Accepted March 02, 2020)

\begin{abstract}
The chemical constituents, antimicrobial and larvicidal activities of essential oils obtained by hydrodistillation of the leaves of Magnolia coco (Lour.) DC. are being reported. The essential oils were analyzed using Gas Chromatography-Flame Ionization Detector (GC-FID) and Gas Chromatography-Mass Spectrometry (GCMS) while the larvicidal activity was evaluated by the protocol of the World Health Organization (WHO). The microbroth dilution assay was used for the study of antimicrobial activity. The major compounds in the oil were sabinene (35.4\%) and $\beta$-pinene (16.3\%). The oil exhibited 100\% mortality towards Aedes albopictus at $24 \mathrm{~h}$ and concentrate of $50 \mu \mathrm{g} / \mathrm{mL}$ while maximum mortality was shown against Ae. aegypti and Culex quinquefasciatus at concentration of $100 \mu \mathrm{g} / \mathrm{mL}$. The median lethal concentrations, LC 50 , values of 11.01, 46.46 and $87.61 \mu \mathrm{g} / \mathrm{mL}$ were obtained against Ae. albopictus, Ae. aegypti and Cx. quinquefasciatus respectively at $24 \mathrm{~h}$. However, the $\mathrm{LC}_{50}$ values at $48 \mathrm{~h}$ period were $10.40,41.98$ and $53.86 \mu \mathrm{g} / \mathrm{mL}$ respectively. In addition, the oil exhibited antimicrobial activity against Enterococcus faecalis ATCC 299212, Staphylococcus aureus ATCC 25923, Bacillus cereus ATCC 14579 and Candida albicans ATCC 10231 with minimum inhibitory concentrations (MIC) values of 128.0, 256.0, 128.0 and $64.0 \mu \mathrm{g} / \mathrm{mL}$ respectively, while the $\mathrm{IC}_{50}$ values were $64.33,128.4,65.33$ and $32.33 \mu \mathrm{g} / \mathrm{mL}$ respectively. These reports, the first of its kind, indicate the potentials of $M$. coco leaf oil as a source of antimicrobial and larvicidal agents.
\end{abstract}

Keywords: Magnolia coco; essential oil; monoterpenes; antimicrobial activity; larvicidal activity. (C) 2020 ACG Publications. All rights reserved.

\section{Plant Source}

Vietnam is a country blessed with many plants which are yet to be exploited for their economic and medicinal values. Previously the chemical constituents and biological potentials activities of essential oils from some of the plants have been reported [1-3]. The leaves of M. coco were collected from Pù Mát National Park, Nghệ An Province (GPS: $19^{\circ} 20^{\prime} \mathrm{N} 104^{\circ} 50^{\prime} \mathrm{E}$ ), Vietnam, in August 2018. A voucher specimen NTC 759 was deposited at the Museum of the Institute of Tropical Biology, Vietnam.

\footnotetext{
* Corresponding author: E-Mail: isiakaogunwande@gmail.com (I.A. Ogunwande); huong223@gmail.com (Le T. Huong)
} 


\section{Previous Studies}

The phytochemical compounds isolated from $M$. coco were magnolamide, magnolone episesamin, sesamin, magnolol, fargesin, aschantin, epi-eudesmin, syringaresinol, syringaresinol-O- $\beta$-Dglucopyranoside, scoparone, $o x o$ - anolobine, and dicentrinone [4]. Studies on secondary metabolites of $M$. coco yielded alkaloids the liriodenine, magnoflorine, salicifoline, anolobine, stephanine and magnococline from the bark, as well as $\mathrm{N}$-acetylanolobine, dicentrinone and oxo-anolobine from the leaves [5]. The polyphenols namely kobusin, (+)-sesamin, epi-catechin, chlorogenic acid and rutin were isolated from the flowers [6]. A methanol extract showed antioxidant activity [7]. The procyanidin oligomer and epicatechin isolated from the flower showed remarkable inhibitory effect on advanced glycation end-products (AGE) formation which suggests the potential for the flowers to play a role in prevent of age-related processes and diseases and/or an anti-skin aging cosmeceutical [6]. The main constituents of essential oils of $M$. coco from Guangxi, China were $\alpha$-pinene, nerolidol, caryophyllene, germacrene $\mathrm{D}$ and bicyclogermacrene [8].

\section{Present Study}

The average yield of the essential oil was $0.63 \pm 0.01 \%(\mathrm{v} / \mathrm{w})$, calculated on a dry weight basis. Figure 1 indicate the chromatoram of the essential oil obtained on HP-5MS column. Thirty-four constituents accounting for $94.5 \%$ of the volatile contents were identified in the oil as seen in Table 1 . The main classes of compounds present therin includes monoterpene hydrocarbons (69.5\%), oxygenated monoterpenes $(2.4 \%)$, sesquiterpene hydrocarbons (19.9\%), oxygenated sesquiterpenes $(2.5 \%)$ and nonterpenes $(0.2 \%)$. The major compounds of essential oil were sabinene $(35.4 \%)$ and $\beta$-pinene (16.3\%). Other notable constituents were $\alpha$-pinene $(7.1 \%), \beta$-elemene $(6.2 \%)$ and $\beta$-caryophyllene $(6.2 \%)$. The principal components of the oil analyzed from China namely $\alpha$-pinene, nerolidol, caryophyllene, germacrene D and bicyclogermacrene [8] were identified in the present sample in much lower amount. The composition of M. coco was similar to M. virginiana L., M. hypolampra (Dandy) Figlar and M. calophylla (Lozano) Govaerts [9] only in the large content of its $\beta$-pinene. However, sabinene, a major constituent of $M$. coco has not been reported previously as significant compound of other Magnolia oil samples [9].

Table 1. Constituents of the leaf essential oil of Magnolia coco

\begin{tabular}{|c|c|c|c|c|}
\hline Sr. No & Compound ${ }^{\text {a }}$ & RI (Exp.) & Range of $\mathrm{RI}^{\mathrm{b}}$ & M. $\operatorname{cocos}^{\mathrm{c}}$ \\
\hline 1. & $\alpha$-Thujene & 930 & $921-939$ & 0.6 \\
\hline 2. & $\alpha$-Pinene & 937 & 924-941 & 7.1 \\
\hline 3. & Camphene & 954 & 933-954 & 0.5 \\
\hline 4. & Sabinene & 979 & 944-980 & 35.4 \\
\hline 5. & $\beta$-Pinene & 983 & 964-985 & 16.3 \\
\hline 6. & Myrcene & 990 & $981-993$ & 2.9 \\
\hline 7. & $\alpha$-Terpinene & 1020 & 1014-1024 & 1.1 \\
\hline 8. & $\beta$-Phellandrene & 1032 & $1026-1032$ & 0.6 \\
\hline 9. & Limonene & 1034 & $1028-1038$ & 1.5 \\
\hline 10. & (Z)- $\beta$-Ocimene & 1038 & $1027-1044$ & 1.3 \\
\hline 11 & (E)- $\beta$-Ocimene & 1049 & $1041-1054$ & 0.2 \\
\hline 12. & $\gamma$-Terpinene & 1062 & $1042-1064$ & 1.6 \\
\hline 13. & cis-Sabinene hydrate & 1074 & 1071-1101 & 0.1 \\
\hline 14. & Terpinolene & 1092 & $1071-1093$ & 0.4 \\
\hline 15. & Linalool & 1102 & 1098-1106 & 0.4 \\
\hline 16. & (E)-4,8-Dimethylnona-1,3,7-triene & 1118 & $1116-1120$ & 0.2 \\
\hline 17. & Terpinen-4-ol & 1187 & 1174-1206 & 1.6 \\
\hline 18. & $\alpha$-Copaene & 1388 & $1367-1394$ & 0.3 \\
\hline
\end{tabular}


Table 1 continued..

\begin{tabular}{|c|c|c|c|c|}
\hline 19. & $\beta$-Elemene & 1404 & $1385-1407$ & 6.2 \\
\hline 20. & $\beta$-Caryophyllene & 1437 & $1416-1451$ & 6.2 \\
\hline 21. & trans- $\alpha$-Bergamotene & 1445 & $1427-1446$ & 0.1 \\
\hline 22. & $(Z)-\beta$-Farnesene & 1458 & $1428-1457$ & 0.1 \\
\hline 23. & $\alpha$-Humulene & 1471 & $1434-1488$ & 0.2 \\
\hline 24. & 9-epi-(E)-Caryophyllene & 1477 & $1457-1479$ & 1.3 \\
\hline 25. & Germacrene D & 1498 & $1461-1519$ & 0.7 \\
\hline 26. & $\beta$-Selinene & 1503 & 1464-1509 & 1.1 \\
\hline 27. & Bicyclogermacrene & 1513 & $1483-1532$ & 2.7 \\
\hline 28. & $\beta$-Bisabolene & 1518 & $1489-1547$ & 0.1 \\
\hline 29. & $\beta$-Sesquiphellandrene & 1534 & 1513-1536 & 0.5 \\
\hline 30. & $\delta$-Cadinene & 1532 & $1516-1536$ & 0.4 \\
\hline 31. & $(E)$-Nerolidol & 1568 & $1551-1569$ & 1.8 \\
\hline 32. & Spathulenol & 1598 & $1571-1601$ & 0.2 \\
\hline 33. & Caryophyllene oxide & 1605 & $1578-1613$ & 0.4 \\
\hline \multirow[t]{7}{*}{34.} & Guaiol (=Champacol) & 1614 & $1595-1616$ & 0.1 \\
\hline & \multicolumn{3}{|c|}{ Total } & 94.5 \\
\hline & \multicolumn{3}{|c|}{ Monoterpene hydrocarbons } & 69.5 \\
\hline & \multicolumn{3}{|c|}{ Oxygenated monoterpenes } & 2.4 \\
\hline & \multicolumn{3}{|c|}{ Sesquiterpene hydrocarbons } & 19.9 \\
\hline & \multicolumn{3}{|c|}{ Oxygenatedsesquiterpenes } & 2.5 \\
\hline & \multicolumn{3}{|c|}{ Non-terpenes } & 0.2 \\
\hline
\end{tabular}

${ }^{\text {a }}$ Elution order on HP-5MS column; RI (Exp.) Retention indices on HP-5MS column; ${ }^{\mathrm{b}}$ Range of LRI Literature retention indices on HP-5MS column as seen in NIST [10]; ${ }^{\mathrm{c}}$ Standard deviation were insignificant and excluded from the Table to avoid congestion; Sr. No. serial Number

Larvicidal activity of the essential oil; The mortality $(\%)$ and minimum lethal concentrations $\left(\mathrm{LC}_{50}\right)$ displayed by the essential oils towards the mosquito vectors are shown in Table 2 and Table S1. The leaf oil of $M$. coco exhibited $100 \%$ mortality against the larvae of Ae. albopictus under tested concentrations of 50 and $100 \mu \mathrm{g} / \mathrm{mL}$ at $24 \mathrm{~h}$ and at concentrations of $25-100 \mu \mathrm{g} / \mathrm{mL}$ for $48 \mathrm{~h}$ period. However, this highest mortality was achieved with Ae. aegypti and $C x$. quinquefasciatus only at concentration of $100 \mu \mathrm{g} / \mathrm{mL}$ when tested at $24 \mathrm{~h}$ and $48 \mathrm{~h}$.

Table 2. Mortality and larvicidal activity of the leaf essential oil of Magnolia coco

\begin{tabular}{|c|c|c|c|c|c|}
\hline \multirow{3}{*}{ Mosquito larva } & \multicolumn{4}{|c|}{ Mortality (\%) ${ }^{a}$} & \\
\hline & \multicolumn{4}{|c|}{ Concentration $(\mu \mathrm{g} / \mathrm{mL})^{b}$} & \\
\hline & 12.5 & 25 & 50 & 100 & \\
\hline \multicolumn{6}{|l|}{ Ae. albopictus } \\
\hline $24 \mathrm{~h}$ & $48.75 \pm 4.349$ & $93.75 \pm 1.893$ & $100.0 \pm .000$ & $100.0 \pm .000$ & \\
\hline $48 \mathrm{~h}$ & $61.25 \pm 4.349$ & $100.0 \pm .000$ & $100.0 \pm .000$ & $100.0 \pm .000$ & \\
\hline \multicolumn{6}{|l|}{ Ae. aegypti } \\
\hline $24 \mathrm{~h}$ & $7.5 \pm .577$ & $17.5 \pm 1.291$ & $17.5 \pm 2.000$ & $100.0 \pm .000$ & \\
\hline $48 \mathrm{~h}$ & $10.0 \pm .000$ & $20.0 \pm 0.816$ & $33.75 \pm 2.000$ & $100.0 \pm .000$ & \\
\hline \multicolumn{6}{|l|}{ Cx. quinquefasciatus } \\
\hline $24 \mathrm{~h}$ & 0 & $5.0 \pm .000$ & $13.75 \pm 1.732$ & $100.0 \pm .000$ & \\
\hline $48 \mathrm{~h}$ & 0 & $16.25 \pm 1.258$ & $42.5 \pm 1.258$ & $100.0 \pm .000$ & \\
\hline \multicolumn{6}{|c|}{ Minimum lethal concentration $(\mu \mathrm{g} / \mathrm{mL})$} \\
\hline & & $\mathbf{L C}_{50}$ & & $\mathrm{LC}_{90}$ & \\
\hline & & $24 \mathrm{~h}$ & $48 \mathrm{~h}$ & $24 \mathrm{~h}$ & $48 \mathrm{~h}$ \\
\hline Ae. albopictus & & 11.01 & 10.40 & 21.20 & 18.42 \\
\hline Ae. aegypti & & 46.46 & 41.98 & 141.30 & 18.98 \\
\hline Cx. quinquefasciatus & & 87.61 & 53.86 & 230.68 & 134.82 \\
\hline
\end{tabular}

${ }^{\mathrm{a}} \mathrm{n}=4$; ${ }^{\mathrm{b}}$ no mortality in the EtOH used as negative control 
The ethanol used as negative control did not show any mortality to the insects. It can be inferred that the oil was more susceptible to Ae. albopictus than other mosquito vectors. The oil showed increased mortality and inhibition of Ae. aegypti and Cx. quinquefasciatus as concentration increases. The larvicidal activity of the oil was confirmed further by the level of minimum inhibitory concentrations displayed towards the mosquito vectors. The leaf oil of $M$. coco displayed larvicidal action towards Ae. albopictus with $\mathrm{LC}_{50}$ values of $11.01 \mu \mathrm{g} / \mathrm{mL}(24 \mathrm{~h})$ and $10.40 \mu \mathrm{g} / \mathrm{mL}(48 \mathrm{~h})$ while the observed $\mathrm{LC}_{90}$ values were $21.20 \mu \mathrm{g} / \mathrm{mL}$ and $18.42 \mu \mathrm{g} / \mathrm{mL}$ respectively. In addition, $\mathrm{LC}_{50}$ values of $46.46 \mu \mathrm{g} / \mathrm{mL}$ and $\mathrm{LC}_{90}$ of 141.30 $\mu \mathrm{g} / \mathrm{mL}$ was exhibited by the oil towards Ae. aegypti at $24 \mathrm{~h}$. The values at $48 \mathrm{~h}$ were $41.98 \mu \mathrm{g} / \mathrm{mL}$ and $128.98 \mu \mathrm{g} / \mathrm{mL}$ respectively. Moreover, $M$. coco leaf oil also inhibited $C x$. quinquefasciatus with $\mathrm{LC}_{50}$ of $87.61 \mu \mathrm{g} / \mathrm{mL}$ and $53.86 \mu \mathrm{g} / \mathrm{mL}$ at $24 \mathrm{~h}$ and $48 \mathrm{~h}$ respectively. The $\mathrm{LC}_{90}$ values obtained at $24 \mathrm{~h}$ and $48 \mathrm{~h}$ respectively were $230.68 \mu \mathrm{g} / \mathrm{mL}$ and $134.82 \mu \mathrm{g} / \mathrm{mL}$. On the other hand, the standard drug, permethrin, which was used as positive control displayed activity at lower $\mathrm{LC}_{50}$ and $\mathrm{LC}_{90}$ values. From Table $\mathrm{S} 2$, the model summary indicated that $93.6 \%, 99.6 \%$ and $96.0 \%$ of Ae. albopictus, Ae. aegypti and Cx. quinquefasciatus, respectively, were killed. From Table S2, all analytical data are significant at $1 \%$ level. There exist a significant relationship between the effectiveness of the essential oil and the mortality of the mosquito vectors. The essential oil was more effective against Ae. aegypti with sum of square of 1179.98 and $\mathrm{F}$ statistics of 4107.78 , followed by $C x$. quinquefasciatus (1021.98 sum of square and $359.76 \mathrm{~F}$ statistics), and lastly Ae. albopictus having the sum of square of 340.11, with F statistics of 220.43

There are scanty reports describing the larvicidal activity of genus Magnolia L. in particular and the family Magnoliaceae in general. Magnolia grandiflora L. exhibited larvicidal activity against Ae. aegypti with $\mathrm{LD}_{50}$ values between 51.5 and $54.7 \mathrm{ppm}$ [11]. The seed essential oil of $M$. denudata Desr. exhibited action against Ae. aegypti, Ae. albopicus and $C x$. p. pallens larvae with $\mathrm{LC}_{50}$ of 19.30, 21.40 and $19.60 \mu \mathrm{g} / \mathrm{mL}$ respectively [12].The leaf oil of Magnolia dandyi Garnep. showed good mortality and larvicidal activity on Ae. albopictus with $\mathrm{LC}_{50}$ values of 29.57 and $29.02 \mu \mathrm{g} / \mathrm{mL}$ respectively at 24 and 48 $\mathrm{h}$ [1]. The oil of Manglietia garrettii Craib showed good repellent activity towards Ae. aegypti, Ae. albopicus and $C x$. quinquefasciatus [13]. The present results showed that $M$. coco oil exhibited mortality and larvicidal action comparable to other oil samples in the family screened for the same purpose.

Antimicrobial activity of the oil; The results of the antimicrobial test on $M$. coco essential oil are shown in Table 3. The oil displayed antimicrobial activity against four of the tested microorganisms with reasonable MIC values. The oil was active against E. faecalis ATCC 299212 and B. cereus ATCC 14579 with MIC value of $128.0 \mu \mathrm{g} / \mathrm{mL}$ and $\mathrm{IC}_{50}$ values of 64.33 and $65.33 \mu \mathrm{g} / \mathrm{mL}$, respectively. The oil inhibited the growth of $S$. aureus ATCC 25923 with MIC and $\mathrm{IC}_{50}$ values of 256.0 and $128.4 \mu \mathrm{g} / \mathrm{mL}$, respectively, which are double the values obtained for E. faecalis ATCC 299212 and B. cereus ATCC 14579. However, the antimicrobial activity was more pronounced with $C$. albicans ATCC 10231 at MIC and IC $_{50}$ values of 64.0 and $32.33 \mu \mathrm{g} / \mathrm{mL}$, respectively. The oil, however, did not show any activity against Escherichia coli ATCC25922, Pseudomonas aeruginosa ATCC27853 and Salmonella enterica ATCC13076. This report was the first of its kind aimed at evaluation of the antimicrobial potentials of $M$. coco leaf oil. The antimicrobial activities of essential oils of some Magnolia species were reported previously. The leaf oil of $M$. grandifolia showed MIC of $500 \mu \mathrm{g} / \mathrm{mL}$ against $S$. aureus [14]. The oil of M. liliiflora Desr. displayed antifungal action with MIC in the range 125 to $500 \mu \mathrm{g} / \mathrm{mL}$ [15].

Table 3. Antimicrobial activity of $M$. coco leaf oil

\begin{tabular}{lllll}
\hline \multicolumn{1}{c}{ Microorganisms } & MIC $(\boldsymbol{\mu g} / \mathbf{m L})$ & $\mathrm{IC}_{50}(\boldsymbol{\mu g} / \mathbf{m L})$ & Str & Nst \\
\hline Enterococcus faecalis ATCC299212 & $128.0 \pm 3.021$ & $64.33 \pm 0.912$ & 1.15 & NT \\
Staphylococcus aureus ATCC25923 & $256.0 \pm 2.314$ & $128.4 \pm 0.500$ & 0.98 & NT \\
Bacillus cereus ATCC14579 & $128.0 \pm 1.500$ & $65.33 \pm 1.500$ & 1.83 & NT \\
Candida albicans ATCC10231 & $64.0 \pm 1.02$ & $32.33 \pm 1.100$ & NT & 1.20 \\
\hline
\end{tabular}

- No activity; NT Not tested; Str, Streptomycin; Nst, Nystatine 
The leaf oil of M. hypolampra Dandy was active against S. aureus, S. enterica, E. coli and C. albicans with MIC of $4.1 \mu \mathrm{g} / \mathrm{mL}$ while activity against $B$. subtilis and $P$. aeruginosa were recorded with MIC of 16.4 and $8.2 \mu \mathrm{g} / \mathrm{mL}$, respectively [9]. A report indicated that the antimicrobial activity of $M$. ovata changed with seasonal variations [16]. It could be seen that $M$. coco exhibited antimicrobial action comparable with data from other Magnolia oils screened for their antimicrobial activities.

The significant antimicrobial and larvicidal activities of the essential oil may be due to actions of sabinene and $\beta$-pinene, the two major compounds of $M$. coco. $\beta$-Pinene has shown antimicrobial activity against infection causing organisms such as $S$. aureus [17] and displayed larvicides against Ae. aegypti among others with $\mathrm{LC}_{50}$ of $35.9 \mathrm{ppm}$ [18] and $21.1 \mathrm{ppm}$ [19]. Sabinene exhibited significant larvicidal activity against Ae. aegypti and Ae. albopictus with $\mathrm{LC}_{50}$ values of 74.1 and $39.5 \mu \mathrm{g} / \mathrm{mL}$ respectively [20]. There are reports describing the antimicrobial activity of sabinene [21]. The synergistic effects of the minor compounds of the essential oil may also be taken into consideration. Some compounds such as limonene, $\alpha$-terpinene, $\gamma$-terpinene, $\alpha$-terpineol, terpinen-4-ol, $\beta$-caryophyllene, $\alpha$-pinene and nerolidol that were present in the oil have demonstrated potent larvicidal actions against Aedes and Culex species [12] as well as antimicrobial efficacy [22].

In conclusion, in this study, the main constituents of the leaf oil of $M$. coco were identified as sabinene and $\beta$-pinene which differs from a previous analyzed sample. Moreover, the essential oil for the first time was shown to have displayed larvicidal activity against Ae. albopictus, Ae. aegypti and $C x$. quinquefasciatus. Also, the essential oil was effectively inhibited the growth of standard strains of E. faecalis, S. aureus, B. cereus and C. albicans with reasonable $\mathrm{MIC}$ and $\mathrm{IC}_{50}$ thus depicting the antimicrobial activity.

\section{Acknowledgments}

We are grateful to Dr. AbduRauf Miftahudeen, Associate Professor, Department of Agricultural Economics, Ladoke Akintola University of Technology, Ogbomoso, for his assistant in statistical analysis.

\section{Supporting Information}

Supporting Information accompanies this paper on http://www.acgpubs.org/journal/records-ofnatural-products

\section{ORCID}

Nguyen T. Chung: 0000-0002-0199-6001

Le T. Huong: 0000-0003-1123-2037

Isiaka A. Ogunwande: 0000-0002-5423-887X

\section{References}

[1] P.H. Ban, L.D. Dinh, L.T. Huong, T.M. Hoi, N.H. Hung, D.N. Dai and I.A. Ogunwande (2020). Mosquito larvicidal activity on Aedes albopictus and constituents of essential oils from Manglietia dandyi (Gagnep.), Rec. Nat. Prod. 14, 201-206.

[2] T.M. Hoi, D.N. Dai, C.T.T. Ha, H.V. Anh and I.A. Ogunwande (2019). Essential oil constituents from the leaves of Anoectochilus setacues, Codonopsis javanica and Aristiochia kwangsiensis from Vietnam, Rec. Nat. Prod. 13, 281-286.

[3] L.T. Huong, H.V. Chinh, N.T.G. An, N.T Viet, N.H. Hung, N.T.H. Thuong, O.A. Giwa-Ajeniya and I.A. Ogunwande (2020). Zingiber zerumbet rhizome essential oil: chemical compositions, antimicrobial and mosquito larvicidal activities, Eur. J. Med. Plants. 30, 1-12.

[4] H.J. Yu, C.C. Chen, B.J. Shieh (1998). Two new constituents from the leaves of Magnolia coco, J. Nat Prod. 61, 1017-1019.

[5] H.J. Yu, C.C. Chen, B.J. Shieh (2013). The constituents from the leaves of Magnolia coco, J. Chin. Chem. Soc. 45, 773-778. 
[6] N. Kato, S. Kawabe, N. Ganeko, M. Yoshimura, Y. Amakura and H. Ito (2017). Polyphenols from flowers of Magnolia coco and their anti-glycation effects, Biosci. Biotechnol. Biochem. 81, 1285-1288.

[7] C. I. Hanafi, H. Rochaeni, P.S. Lestari and M. Sukiman (2017). Evaluation of DPPH free radical scavenging activity of Magnolia coco flowers, Int. J. Chem Stud. 5, 770-772.

[8] X.Y. Zhu, M.M. Shao, H.J. Zhang and R.M. Lu (2011). Analysis of chemical constituents of essential oils from Magnolia coco by GC-MS, Chinese J. Exp. Trad. Med. Form. 16, 3-6.

[9] C.T.T. Ha, T.H. Thai, N.T. Hien, H.T.V. Anh, L.N. Diep, D.T.T. Thuy, D.D. Nhat and W.N. Setzer (2019). Chemical composition and antimicrobial activity of the leaf and twig essential oils of Magnolia hypolampra growing in Na Hang Nature Reserve, Tuyen Quang Province, Vietnam, Nat. Prod. Commun. 14, 1-7.

[10] National Institute of Science and Technology (2018). Chemistry Web Book. Data from NIST Standard Reference Database 69.

[11] J.U. Rehman, A. Ali, N. Tabanca, V. Raman, B. Demirci, K.H.C. Başer and I.A. Khan (2013). Biting deterrent and larvicidal activity of essential oils of Magnolia grandiflora against Aedes aegypti, Planta Med. 79, P-20.

[12] Z.Q. Wang, H. Perumalsamy, M. Wang, S. Shu and Y.J. Ahn (2015). Larvicidal activity of Magnolia denudata seed hydrodistillate and related compounds and liquid formulations towards two susceptible and two wild mosquito species, Pest Manag. Sci. 72, 897-906.

[13] A. Tawatsin, P. Asavadachanukorn, U. Thavara, P. Wongsinkongman, J. Bansidhi, T. Boonruad, P. Chavalittumrong, N. Soonthornchareonnon, N. Komalamisra and M.S. Mulla (2006). Repellency of essential oils extracted from plants in Thailand against four mosquito vectors (Diptera: Culicidae) and oviposition deterrent effects against Aedes aegypti (Diptera: Culicidae), South East Asian J. Trop. Med. 37, 915-931.

[14] L. Guerra-Boone, R. Alvarez-Román, R. Salazar-Aranda, A. Torres-Cirio, V.M. Rivas-Galindo, N. Waksman de Torres, G.M. González and L.A. Pérez-López (2013). Chemical compositions and antimicrobial and antioxidant activities of the essential oils from Magnolia grandiflora, Chrysactinia mexicana, and Schinus molle found in northeast Mexico, Nat. Prod. Commun. 8,135-138.

[15] V.K. Bajpai and S.C. Kang (2012). In vitro and in vivo inhibition of plant pathogenic fungi by essential oil and extracts of Magnolia lilliiflora Desr, J. Agric. Sci. Technol. 14, 845-846.

[16] M.E.A. Stefano, M.J. Salvador, I.Y. Ito, A. Wisniewski Jr., E.L. Simionattoa and R. Mello-Silva (2008). Chemical composition, seasonal variation and evaluation of antimicrobial activity of essential oils of Talauma ovata A. St. Hil. (Magnoliaceae), J. Essent. Oil Res. 20, 565-569.

[17] A.M. Leite, E.O. Lima, E.L. Souza, M. Diniz, V.N. Trajano and I.A. Medeiros (2007). Inhibitory effect of $\alpha$-pinene, $\beta$-pinene and eugenol on the growth of potential infectious endocartidis causing gram-positive bacteria, Braz. J. Pharm. 43, 121-126.

[18] A. Ali, N. Tabanca, M. Kurkcuoglu, A. Duran, E.K. Blythe and I.A. Khan (2014). Chemical composition, larvicidal, and biting deterrent activity of essential oils of two subspecies of Tanacetum argenteum (Asterales: Asteraceae) and individual constituents against Aedes aegypti (Diptera: Culicidae), J. Med. Entomol. 51, 824-830

[19] A. Lucia, G.A. Audino, E. Seccacini, S. Licastro, E. Zerba and H. Masuh (2007). Larvicidal effect of Eucalyptus grandis essential oil and turpentine and their major components on Aedes aegypti larvae, J. Ame. Mosq. Cont. Assoc. 23, 299-303.

[20] S.S. Cheng, C.Y. Lin, M.J. Chung, Y.H. Liu, C.G. Huang and S.T. Chang (2013). Larvicidal activities of wood and leaf essential oils and ethanolic extracts from Cunninghamia konishii Hayata against the dengue mosquitoes, Ind. Crop Prod. 47, 310-315.

[21] R. Arunkumar, S.A. Nair, K.B. Rameshkumar and A. Subramoniam (2014). The essential oil constituents of Zordia diphylla (L.) Pers, and anti-inflammatory and antimicrobial activities of the oil, Rec. Nat. Prod. 8, 385-393.

[22] M.K. Swamy, M.S. Akhtar and U.R. Sinniah (2016). Antimicrobial properties of plant essential oils against human pathogens and their mode of action: an updated review, Evid. Based Complement. Alter. Med. 2016: Article ID 3012462, 12 pages.

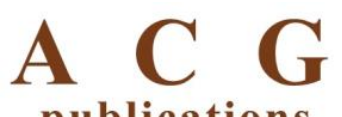

publications

(C) 2020 ACG Publications 